\title{
Mineralisation of distinct biogas digestate qualities directly after application to soil
}

\author{
Laura Barduca $^{1,2,3} \cdot$ Stefanie Wentzel ${ }^{1,4} \cdot$ Reiner Schmidt $^{5} \cdot$ Mario Malagoli $^{2} \cdot$ Rainer Georg Joergensen $^{1}$ (I)
}

Received: 9 July 2020 / Revised: 8 October 2020 / Accepted: 23 October 2020 / Published online: 2 November 2020

(C) The Author(s) 2020

\begin{abstract}
Biogas is an important energy source produced by the anaerobic fermentation of raw faecal slurries and plant residues. Separation of the total digestate increases the fertilizer quality of the liquid fraction and the carbon sequestration potential of the solid fraction. A 12-day incubation study was carried out to investigate the relationships between the chemical composition of different digestate qualities and the immediate response of soil microbial activity and biomass indices. The highest cumulative $(\Sigma) \mathrm{CO}_{2}-\mathrm{C}$ efflux was observed after adding the solid fraction and lowest after adding the liquid fraction to soil, which was even lower than that of the control. The $\Sigma \mathrm{CO}_{2}$-C efflux showed the strongest negative correlation with the raw ash and strong positive correlations with the raw fibre concentration and the $\mathrm{C} / \mathrm{N}$ ratio of the different digestate qualities. The highest and similar $\Sigma \mathrm{N}_{2} \mathrm{O}-\mathrm{N}$ efflux was observed after adding the total digestate or the liquid fraction, which were equivalent to approximately $1 \%$ of added $\mathrm{N}$. This relatively low percentage indicates a possible origin from nitrifier denitrification. Total digestate and its liquid fraction exhibited considerable net- $\mathrm{N}$ mineralisation rates, which could mainly be predicted by the $\mathrm{C} / \mathrm{N}$ ratios of the different digestate qualities. Microbial biomass $\mathrm{C}$ did not respond to the application of any digestate quality, whereas the fungal ergosterol content increased after applying the solid and the composted solid fractions. This raw fibre-induced fungal growth led to strong net-N immobilisation in soil after applying these two digestate qualities.
\end{abstract}

Keywords Raw slurry $\cdot$ Fermented slurry $\cdot$ Fertilizer $\cdot$ Compost $\cdot$ C sequestration $\cdot$ Soil microorganisms

\section{Introduction}

Biogas is an important energy source produced by the anaerobic fermentation of raw faecal slurries and plant residues (Blumenstein et al. 2015; Möller 2015). In the early eighties of the last century, biogas plants were installed by several

Rainer Georg Joergensen

joerge@uni-kassel.de

1 Soil Biology and Plant Nutrition, University of Kassel, Nordbahnhofstr.1a, 37213 Witzenhausen, Germany

2 Department of Agronomy, Food, Natural Resources, Animals and the Environment, University of Padua, Agripolis, 35020 Legnaro, Italy

3 Present address: Barduca Bio, Via Piovega 41/c - 49, Borgoricco 35010, Italy

4 Present address: Nagola Re GmbH, Alte Bahnhofstraße 65 (Friedrichshof), 03197 Jänschwalde, Germany

5 Demeter Extension Service Hohenlohe, Eckhartshäuserstr. 41, 74532 Ilshofen, Germany biodynamic farmers in north-east Baden-Württemberg, Germany, to gain independence from nuclear power electricity, which was strongly expanding during that time (Wentzel et al. 2015).

Biogas production is accompanied by the formation of digestates, which are usually applied to crops as fertilizer. However, odour and pathogen reduction as well as higher fertilizer quality in comparison with raw slurries were further reasons for using biogas digestates as fertilizers (Goberna et al. 2011; Möller and Müller 2012). Anaerobic digestion reduces dry matter (DM) concentrations and, thus, digestate $\mathrm{C} / \mathrm{N}$ ratios, combined with increased $\mathrm{NH}_{4}{ }^{+}$concentrations and an increase in pH (Bauer et al. 2009; Möller and Müller 2012). This led to positive biogas digestate effects on plant yield in comparison with other organic fertilizers, e.g. farmyard manure (Odlare et al. 2008; Bauer et al. 2009; Sänger et al. 2010), raw slurries (Bachmann et al. 2011; Wentzel and Joergensen, 2016a) or compost (Tambone et al. 2010). In addition, biogas digestates are applied as fertilizer close nutrient cycles in stockless organic farming systems (Stinner et al. 2008). 
Separation of total biogas digestates into a liquid and a solid fraction has gained increasing importance, as the liquid phase has a higher fertilizer quality than the total digestate, due to the increased $\mathrm{NH}_{4}{ }^{+}$concentration (Bauer et al. 2009; Tambone et al. 2017). In addition, a large part of the phosphorus load is transferred to the solid fraction (Bauer et al. 2009; Insam et al. 2015; Hupfauf et al. 2016), which might enable cost-efficient transportation to areas with deficiency (Møller et al. 2000; Bauer et al. 2009; Thomas et al. 2017). The solid fraction is usually composted (Bustamante et al. 2012; de la Fuente et al. 2013) and must be applied to crops with a lower $\mathrm{N}$ demand, due to its $\mathrm{N}$ immobilising properties (Chiyoka et al. 2014).

The current study investigated two biogas plants, which were fed with mixtures of faecal manures and plant residues at similar ratios, typical for biodynamic farms (Wentzel et al. 2015). However, the size of the biogas plants and their feedstock composition differed considerably. The total digestate, the liquid and solid fraction directly after separation as well as the composted solid fraction were examined. The objective of the study was to investigate the relationships between the chemical composition of different digestate qualities and the immediate response of microbial activity and biomass. Important chemical composition indices are, for example, $\mathrm{pH}, \mathrm{C} / \mathrm{N}$ ratio, raw ash and raw fibre (Jørgensen and Jensen 2009; Wentzel and Joergensen 2016a). Important microbial activity indices are $\mathrm{CO}_{2}$ and $\mathrm{N}_{2} \mathrm{O}$ efflux for assessing air pollution (Sänger et al. 2011) and net-N mineralisation for assessing fertilizer quality (de la Fuente et al. 2013). In particular, the threat of high $\mathrm{N}_{2} \mathrm{O}$ effluxes after application of biogas digestates to soil has attracted considerable experimental attention (Möller 2015; Verdi et al. 2019).

The application of total biogas digestates to soil is accompanied by the addition of fermenter-derived microorganisms (Abubaker et al. 2013), which might be reflected by an increased microbial biomass (Chen et al. 2012; Möller, 2015; Wentzel and Joergensen 2016b). This might be different for the liquid fraction, due to the lower organic matter and higher $\mathrm{NH}_{4}{ }^{+}$concentrations. Autochthonous saprotrophic soil fungi often respond with rapid increases to the application or organic matter that contains high concentrations of recalcitrant raw fibre (Chander et al. 2002; Joergensen and Wichern 2008). For these reasons, an incubation study was designed to investigate the following hypotheses: (1) The $\mathrm{N}_{2} \mathrm{O}$ efflux is generally small after applying the distinct digestate qualities. (2) Soil microorganisms do not respond to the application of the liquid fraction. (3) Soil fungi increase after applying the solid and the composted solid fractions. The incubation period was restricted to 12 days, as usually most of the organic fertilizerderived $\mathrm{N}_{2} \mathrm{O}$ is produced directly after application to soil (Sänger et al. 2011; Jost et al. 2013).

\section{Materials and methods}

\section{On-farm biogas production}

Farm K is located in Künzelsau-Garnberg ( $49^{\circ} 17^{\prime} 15.22^{\prime \prime} \mathrm{N}$, $9^{\circ} 42^{\prime} 34.69^{\prime \prime}$ ), Baden-Württemberg, south-central Germany, at $407 \mathrm{~m}$ asl. The farm has been managed according to biodynamic principles (Koepf et al. 1990) of the Demeter organization since 1980. During sampling, the biogas plant consisted of one fermenter $\left(300 \mathrm{~m}^{3}\right)$ and one post-fermenter tank (300 $\mathrm{m}^{3}$ ), producing $30 \mathrm{~kW} \mathrm{~h}^{-1}$. The feedstock for the biogas plant was a mixture of cattle farmyard manure and clover/grass at similar proportions. The farmyard manure was loaded into the plant without pre-treatment, whereas the clover/grass was ensiled prior to loading. The raw materials were loaded with a slurry pump and a screw feeder for the solid inputs. The process temperature was maintained at mesophilic $38-40{ }^{\circ} \mathrm{C}$ without microbial inocula or further process monitoring. The liquid fraction was separated from the digestate with a screw, sieve and press. The solid fraction was composted as a pile, which was turned once every 3-4 weeks.

Farm M is located in Mühlhausen (51 $11^{\circ} 24.14^{\prime \prime} \mathrm{N}, 10^{\circ}$ $25^{\prime} 12.67^{\prime \prime}$ E), Thuringia, east-central Germany, at $254 \mathrm{~m}$ asl. The farm has been managed according to biodynamic principles of the Demeter organization since 1991. During sampling, the biogas plant consisted of one fermenter tank (1600 $\left.\mathrm{m}^{3}\right)$ and three post-fermenter tanks $\left(2300 \mathrm{~m}^{3}, 2 \times 1100 \mathrm{~m}^{3}\right)$, producing on average $220 \mathrm{~kW} \mathrm{~h}^{-1}$. The feedstock for the biogas plant was composed of chicken manure from another farm, cow and pig farmyard manure as well as ensiled energy crops, such as maize, rye and vetch, all approximately at the same percentage of volumes. The feedstock materials are loaded by a scraper and further mixed inside the tank by a blade system with slow movements. The process temperature was maintained at $30-40{ }^{\circ} \mathrm{C}$ without microbial inocula or further process monitoring. The liquid fraction was separated from the digestate with a screw press. The solid fraction was composted in open piles without further turning.

\section{Digestate and soil sampling}

Total digestate, liquid fraction, solid fraction and composted solid fraction were sampled from each farm. Total digestate was taken from the first tank at farm $\mathrm{K}$ and from the second tank at farm M. The liquid and solid fractions were taken immediately after separation. The composted solid fraction samples were taken from the central part of the piles. The compost was 3-4 months old at farm $\mathrm{K}$ and approximately 6 months old at farm M. The four digestate qualities (total digestate, liquid fraction, solid fraction, and composted solid fraction) were each taken in quadruplicate, placed in polyethylene bags, and shock frozen with liquid $\mathrm{N}_{2}$ at $-196^{\circ} \mathrm{C}$. Then, 
the frozen samples were transported to the laboratory and stored at $-18^{\circ} \mathrm{C}$.

The soil used for the incubation experiment was taken $(0-$ $20 \mathrm{~cm})$ with a spade from the arable site Saurasen $\left(51^{\circ} 22^{\prime}\right.$ $35.47^{\prime \prime} \mathrm{N}, 9^{\circ} 53^{\prime} 54.59^{\prime \prime}$ E) near Witzenhausen, Hesse, central Germany (Jost et al. 2013) at $280 \mathrm{~m}$ asl. The soil is derived from eroded loess overlying clayey sandstone and has been classified as Stagnic Luvisol (IUSS Working Group WRB 2015 ). The texture was $6 \%$ sand, $72 \%$ silt and $22 \%$ clay. Soil organic $\mathrm{C}$ and total $\mathrm{N}$ contents were 8.2 and $0.89 \mathrm{mg}$ $\mathrm{g}^{-1}$ soil, respectively, with a soil $\mathrm{pH}-\mathrm{CaCl}_{2}$ of 6.4 . The soil was sieved $(<2 \mathrm{~mm})$ to remove stones and plant residues. Then, the soil was stored at $4{ }^{\circ} \mathrm{C}$ until the experiment started.

\section{Chemical digestate analysis}

The $\mathrm{pH}$ of the four digestate qualities was measured by mixing $10-\mathrm{g}$ fresh sample with $25 \mathrm{ml} 0.01 \mathrm{M} \mathrm{CaCl}_{2}$ solution. In $5 \mathrm{~g}$ of four fresh digestate qualities, total Kjeldahl $\mathrm{N}$ was determined by $\mathrm{H}_{2} \mathrm{SO}_{4}$ digestion and titration as described by Althaus et al. (2013). In 25-g fresh digestate samples, $\mathrm{NH}_{4}{ }^{+}$and $\mathrm{NO}_{3}{ }^{-}$were extracted with $70 \mathrm{ml} 0.05 \mathrm{M} \mathrm{K}_{2} \mathrm{SO}_{4}$ by 30 -min horizontal shaking at $200 \mathrm{rev} \mathrm{min}^{-1}$, followed by filtration and continuous flow analysis (Evolution 2, Alliance Instruments, Friedrichsdorf). In oven-dried digestate samples $\left(60{ }^{\circ} \mathrm{C}\right.$ for 48-72 h), XF (raw fibre) and XA (raw ash) were determined by near-infrared spectroscopy (FOSS 6500, Rellingen, Germany) according to Althaus et al. (2013). Also, in ovendried digestate samples, total $\mathrm{C}$ was measured in a Vario Max $\mathrm{CHN}$ elemental analyser (Elementar, Hanau, Germany).

\section{Microbial biomass and activity indices}

Moist soil (300 g on an oven-dry basis) was fertilised with $10 \mathrm{mg}$ digestate $\mathrm{N}$, approximately equivalent to $75 \mathrm{~kg} \mathrm{~N} \mathrm{ha}^{-1}$. For this reason, the amount of added organic $\mathrm{C}$ varied. In farm $\mathrm{K}$ treatments, 80 (total digestate), 40 (liquid fraction), 210 (solid fraction) and 220 (composted solid fraction) $\mathrm{mg} \mathrm{C}$ were added to $300-\mathrm{g}$ soil. In farm $\mathrm{M}$ treatments, 50 (total digestate), 50 (liquid fraction), 200 (solid fraction) and 240 (composted solid fraction) $\mathrm{mg} \mathrm{C}$ were added to $300 \mathrm{~g}$ soil. After fertilization, each sample was transferred into a $1500-\mathrm{ml}$ hermetic glass jar. Unfertilized control soil and fertilized soil treatments were replicated four times. All samples were incubated in the dark at $22{ }^{\circ} \mathrm{C}$.

Ergosterol was extracted at the start (day 0, directly after application of the four digestate qualities) and end (day 12) of the incubation experiment from 2-g moist soil with 100-ml ethanol for $30 \mathrm{~min}$ by oscillating shaking at $250 \mathrm{rev} \mathrm{\textrm {min } ^ { - 1 }}$ (Djajakirana et al. 1996). Then, ergosterol was measured by reversed-phase HPLC, using 100\% methanol as the mobile phase and detected at a wavelength of $282 \mathrm{~nm}$. Microbial biomass $\mathrm{C}(\mathrm{MBC})$ was determined at start and end of the incubation experiment by fumigation extraction (Vance et al. 1987). Chloroform fumigated and non-fumigated portions of 10 -g moist soil were extracted with $40 \mathrm{ml} 0.5 \mathrm{M} \mathrm{K}_{2} \mathrm{SO}_{4}$. Organic $\mathrm{C}$ in the extracts was determined with a Multi N/C $2100 \mathrm{~S}$ analyser (Analytik Jena, Germany). $\mathrm{MBC}$ was $E_{\mathrm{C}} / k_{\mathrm{EC}}$, where $E_{\mathrm{C}}=$ (organic $\mathrm{C}$ extracted from fumigated soils) - (organic $\mathrm{C}$ extracted from non-fumigated soils) and $k_{\mathrm{EC}}=0.45$ (Wu et al. 1990).

In the extracts of the non-fumigated samples, $\mathrm{NH}_{4}{ }^{+}$and $\mathrm{NO}_{3}{ }^{-}$were determined by continuous flow analysis to estimate net-N mineralisation. Net- $\mathrm{N}$ mineralised from each treatment was calculated as the sum of $\mathrm{NH}_{4}{ }^{+}-\mathrm{N}+\mathrm{NO}_{3}{ }^{-} \mathrm{N}$ at day 12 minus the initial sum of inorganic $\mathrm{N}$.

At days 1,2,3,8 and 12, two 10-ml gas samples were taken with an air tight syringe from the headspace of the incubation jars through a three-layer silicone septum (Hamilton, Reno, USA). The gas samples were immediately analysed for $\mathrm{CO}_{2}$ and $\mathrm{N}_{2} \mathrm{O}$ using a GC-14B (Shimadzu, Kyoto, Japan) gas chromatograph with an electron-capture detector. For calculating cumulative $(\Sigma)$ fluxes, i.e. $\Sigma \mathrm{CO}_{2}$-C efflux and $\Sigma \mathrm{N}_{2} \mathrm{O}-\mathrm{N}$ efflux, hourly $\mathrm{CO}_{2}-\mathrm{C}$ and $\mathrm{N}_{2} \mathrm{O}-\mathrm{N}$ evolution rates were extrapolated to a daily rate; then, the average between two neighbouring sampling days was calculated and multiplied by the incubation period represented by these two days.

\section{Statistical analysis}

The results presented in the tables are arithmetic means and expressed on an oven-dry basis (about $48 \mathrm{~h}$ at $60{ }^{\circ} \mathrm{C}$ for the four digestate qualities and $105^{\circ} \mathrm{C}$ for soil). Data were tested for normality of distribution using Shapiro-Wilks and for equal variance using the Brown-Forsyth test. Ergosterol data were ln-transformed to meet these requirements. The significance of treatment effects was analysed by a two-way ANOVA, using digestate quality and farm as independent factors and sampling date as repeated measures for ergosterol, $\mathrm{MBC}$ and $\mathrm{K}_{2} \mathrm{SO}_{4}$ extractable $\mathrm{C}$ as well as the ergosterol/MBC ratio. ANOVA analysis was carried out with SigmaPlot 13.0 (Systat Inc., San José, USA).

\section{Results}

The liquid fraction exhibited increased concentrations of $\mathrm{NH}_{4}{ }^{+}$, total $\mathrm{N}$ and raw ash, but decreased DM and total $\mathrm{C}$ concentrations in comparison with the total digestate (Table 1). In the solid fraction, $\mathrm{NH}_{4}{ }^{+}$, total $\mathrm{N}$ and XA concentrations were decreased, whereas DM, XF and total $\mathrm{C}$ concentrations were increased in comparison with the total digestate. With a mean $\mathrm{pH}$ of 9.3, the solid fraction exceeded the mean of all other digestate qualities by approximately a $1.0 \mathrm{pH}$ step. The solid and composted solid fractions exhibited only small differences in chemical composition. $\mathrm{DM}, \mathrm{NH}_{4}{ }^{+}$and $\mathrm{XF}$ 
Table 1 Farm-specific chemical composition of different biogas digestate fractions before application to soil

\begin{tabular}{|c|c|c|c|c|c|c|c|c|c|c|}
\hline & Farm & $\mathrm{pH}$ & $\begin{array}{l}\mathrm{DM} \\
(\%)\end{array}$ & $\begin{array}{l}\mathrm{C} \\
(\mathrm{mg} \mathrm{g}\end{array}$ & N & $\mathrm{C} / \mathrm{N}$ & $\begin{array}{l}\mathrm{NO}_{3}^{-}-\mathrm{N} \\
\left(\mathrm{mg} \mathrm{g}^{-1} \mathrm{DM}\right)\end{array}$ & $\mathrm{NH}_{4}{ }^{+}-\mathrm{N}$ & $\begin{array}{l}\mathrm{XF} \\
(\% \mathrm{DM})\end{array}$ & XA \\
\hline \multirow[t]{2}{*}{ Total digestate } & $\mathrm{K}$ & 8.21 & 10.7 & 395 & 47 & 8.5 & 0.01 & 15.5 & 29.9 & 25.3 \\
\hline & M & 8.40 & 9.6 & 351 & 71 & 5.0 & 0.00 & 49.2 & 21.0 & 31.7 \\
\hline \multirow[t]{2}{*}{ Liquid fraction } & $\mathrm{K}$ & 8.25 & 5.0 & 355 & 101 & 3.5 & 0.08 & 59.7 & 6.9 & 36.7 \\
\hline & M & 8.20 & 7.1 & 321 & 95 & 3.4 & 0.01 & 65.2 & 22.6 & 39.1 \\
\hline \multirow[t]{2}{*}{ Solid fraction } & $\mathrm{K}$ & 9.33 & 26.7 & 436 & 20 & 21.8 & 0.00 & 5.7 & 47.4 & 14.0 \\
\hline & M & 9.22 & 29.3 & 443 & 22 & 19.9 & 0.00 & 9.4 & 47.6 & 13.2 \\
\hline Composted & $\mathrm{K}$ & 8.27 & 13.3 & 416 & 20 & 21.4 & 0.51 & 0.6 & 40.4 & 19.6 \\
\hline solid fraction & M & 8.84 & 19.8 & 441 & 19 & 23.8 & 0.08 & 6.0 & 44.7 & 12.8 \\
\hline $\mathrm{CV}( \pm \%)$ & & 1.0 & 4.5 & 1.0 & 5.9 & 6.1 & 28 & 15 & 4.1 & 3.3 \\
\hline
\end{tabular}

$C V$, mean coefficient of variation (standard deviation $/ n \times 100$ ) between replicate samples $(n=4)$, averaged over the four digestate qualities; $D M$, dry matter; $X F$, raw fibre; $X A$, raw ash

concentrations as well as the $\mathrm{pH}$ were lower in the composted than in the solid fraction, whereas the $\mathrm{NO}_{3}{ }^{-}$and XA concentrations were higher.

The highest soil $\mathrm{\Sigma CO}_{2}$-C efflux was observed after adding the solid fraction and lowest after adding the liquid fraction (Table 2), which was even lower than that of the control. Control $\mathrm{CO}_{2}$-C efflux rates were roughly constant throughout the incubation, whereas those from the total digestate and the liquid fraction moderately declined from day 1 (Fig. 1a). In contrast, the $\mathrm{CO}_{2}-\mathrm{C}$ efflux rates from the solid and composted solid fractions continuously increased from day 2 or day 3 until the end of the experiment. The slower increase after adding the composted solid fraction from farm $\mathrm{K}$ led to a

Table 2 Mean biogas digestate quality $\times$ sampling day interactions of the $\mathrm{CO}_{2}-\mathrm{C}$ and $\mathrm{N}_{2} \mathrm{O}-\mathrm{N}$ sums evolved as well as of the net-N mineralised in soil amended with different biogas digestate fractions over a 12-day incubation period at $22^{\circ} \mathrm{C}$; probability levels of a two-way ANOVA,
$\Sigma \mathrm{CO}_{2}-\mathrm{C}$ efflux was positively correlated with the $\mathrm{XF}$ fraction and the $\mathrm{C} / \mathrm{N}$ ratio (both $r=0.66, P<0.001, n=32$ ) of the four digestate qualities.

The highest and similar $\Sigma \mathrm{N}_{2} \mathrm{O}-\mathrm{N}$ efflux was observed after adding the total digestate or the liquid fraction (Table 2). The $\Sigma \mathrm{N}_{2} \mathrm{O}-\mathrm{N}$ efflux of the solid and composted solid fractions exceeded the very low value of the control in each case. The $\mathrm{N}_{2} \mathrm{O}$ efflux rates declined from maximum values at day 1 to roughly constant values from day 8 on (Fig. 1b). An exception was the composted solid fraction from farm $\mathrm{K}$, where the $\mathrm{N}_{2} \mathrm{O}$ efflux rates remained constant throughout the incubation. The $\Sigma \mathrm{N}_{2} \mathrm{O}-\mathrm{N}$ efflux could be predicted by a linear combination of the digestate $\mathrm{C} / \mathrm{N}$ ratios and the $\Sigma \mathrm{CO}_{2}-\mathrm{C}$ efflux, with an ad-

using digestate quality and farm origin as factors and sampling day as repeated measures and excluding the control soil from statistical evaluation

\begin{tabular}{llcr}
\hline & $\begin{array}{l}\Sigma \mathrm{CO}_{2} \\
\left(\mu \mathrm{g} \mathrm{g} \mathrm{g}^{-1} \text { soil }\right)\end{array}$ & $\begin{array}{l}\Sigma \mathrm{N}_{2} \mathrm{O} \\
\left(\mathrm{ng} \mathrm{N} \mathrm{g}^{-1} \text { soil }\right)\end{array}$ & $\begin{array}{l}\text { Net-N mineralisation } \\
\left(\mu \mathrm{g} \mathrm{N} \mathrm{g} \mathrm{soil} \mathrm{d}^{-1}\right)\end{array}$ \\
\hline Total digestate & 268 & 31.8 & 28 \\
Liquid fraction & 197 & 31.7 & 59 \\
Solid fraction & 359 & 14.6 & -33 \\
Composted solid fraction & 303 & 6.5 & -44 \\
Control soil & 221 & 0.4 & -16 \\
Probability levels & & $<0.01$ & $<0.01$ \\
Digestate quality & $<0.01$ & 0.02 & $\mathrm{NS}$ \\
Farm & $\mathrm{NS}$ & $\mathrm{NS}$ & $\mathrm{NS}$ \\
Digestate $\times$ farm & $<0.01$ & 28 & 110 \\
CV $( \pm \%)$ & 11 & 28 & \\
\hline
\end{tabular}

$C V$, mean coefficient of variation (standard deviation $/ n \times 100)$ between replicate samples $(n=4)$, averaged over the five treatments; $N S$, not significant

significant digestate $\times$ farm interaction (Table 3). The justed $r^{2}$ of 0.80 (Fig. 2). Net-N mineralisation was higher 

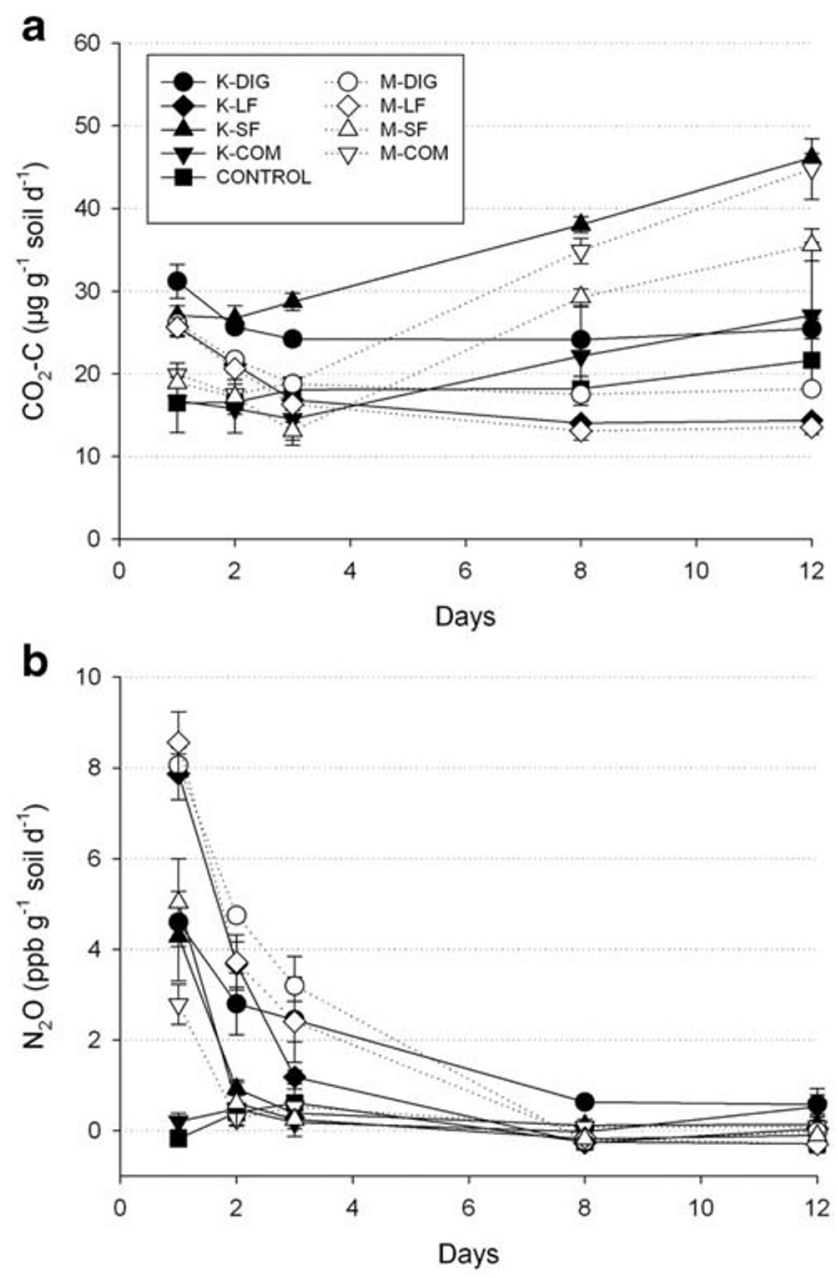

Fig. 1 a $\mathrm{CO}_{2}-\mathrm{C}$ efflux and $\mathbf{b} \mathrm{N}_{2} \mathrm{O}$ efflux from soil amended with biogas digestate fractions over a 12-day incubation at $22{ }^{\circ} \mathrm{C}$; error bars indicate one standard error of mean; DIG, total digestate; LF, liquid fraction; SF, separated fraction; COM, composted solid fraction

after liquid fraction than after total digestate application, whereas net-N immobilisation was higher after composted solid than after fresh solid fraction application (Table 2). Net-N mineralisation was positively correlated with the XA fraction $(r=0.80, P<0.0001, n=32)$ and negatively with the $\mathrm{C} / \mathrm{N}$ ratio $(r=-0.74, P<0.0001)$ of the four digestate qualities.

The mean $\mathrm{K}_{2} \mathrm{SO}_{4}$ extractable $\mathrm{C}$ content was generally higher after adding the four digestate qualities from farm $\mathrm{K}$ than from farm $\mathrm{M}$ and significantly declined during the incubation (Table 3). This was true for all digestate qualities, but not for the control soil (Fig. 3a). Mean MBC generally increased during the incubation but did not specifically respond to the addition of any digestate quality (Table 3). Like MBC, the soil ergosterol content increased during the incubation, mainly after adding the solid and composted solid fractions, but not after adding the total digestate or the liquid fraction (Fig. 3b). This led to a significant digestate quality $\times$ day

Table 3 Main effects of sampling day $(n=2)$, farm $(n=2)$, and digestate quality ( $n=4+$ control) on the contents of $\mathrm{K}_{2} \mathrm{SO}_{4}$ extractable $\mathrm{C}, \mathrm{MBC}$ and ergosterol amended with four biogas digestate qualities at the start (day 0 ) and end (day 12) of an incubation at $22{ }^{\circ} \mathrm{C}$; probability levels of a two-way ANOVA, using digestate quality and farm origin as factors and sampling day as repeated measures and excluding the control soil from statistical evaluation

\begin{tabular}{llll}
\hline & $\begin{array}{l}\mathrm{K}_{2} \mathrm{SO}_{4} \text { extractable C } \\
\left(\mu \mathrm{g} \mathrm{g}^{-1} \text { soil }\right)\end{array}$ & $\mathrm{MBC}$ & Ergosterol \\
\hline Day 0 & 48.8 & 218 & 0.42 \\
Day 12 & 42.1 & 264 & 0.51 \\
Farm K & 46.7 & 240 & 0.48 \\
Farm M & 43.3 & 243 & 0.45 \\
Total digestate & 42.3 & 247 & 0.40 \\
Liquid fraction & 42.3 & 217 & 0.38 \\
Solid fraction & 46.8 & 231 & 0.58 \\
Composted solid fraction & 48.6 & 270 & 0.51 \\
Control soil & 42.8 & 244 & 0.54 \\
Probability values & & & \\
Digestate quality & $<0.01$ & $\mathrm{NS}$ & 0.01 \\
Farm & 0.01 & $\mathrm{NS}$ & $\mathrm{NS}$ \\
Incubation day & $<0.01$ & 0.01 & 0.01 \\
Digestate $\times$ farm & $\mathrm{NS}$ & $\mathrm{NS}$ & $\mathrm{NS}$ \\
Digestate $\times$ day & $\mathrm{NS}$ & $\mathrm{NS}$ & 0.02 \\
Farm $\times$ day & $\mathrm{NS}$ & $\mathrm{NS}$ & $\mathrm{NS}$ \\
CV $( \pm \%)$ & 11 & 24 & 20 \\
\hline
\end{tabular}

$C V$, mean coefficient of variation (standard deviation $/ n \times 100$ ) between replicate samples $(n=4)$, averaged over the five treatments; $N S$, not significant

interaction (Table 3). The ergosterol content at day 12 was positively correlated with the $\Sigma \mathrm{CO}_{2}$-C efflux $(r=0.60, P<$ $0.05, n=32)$ and the XF fraction $(r=-0.64, P<0.001)$ but negatively with net-N mineralisation $(r=-0.65, P<0.001)$.

\section{Discussion}

Each of the four digestate qualities behaved similarly after application to soil, although obtained from two very different production systems, based on animal slurries and plant residues. In the current study, the separation of the total biogas digestate resulted on average in an $81 \%$ liquid fraction with $6 \% \mathrm{DM}$ and in a $19 \%$ solid fraction with $28 \% \mathrm{DM}$. These data are in line with Bauer et al. (2009), who reported that separation produced a $79.2 \%$ fluid phase with $4.5 \% \mathrm{DM}$ and a $20.8 \%$ solid phase with $19.3 \%$ DM. Some liquid digestate properties of farm $\mathrm{K}$ were already analysed 3 years before (Wentzel and Joergensen 2016a). The similarity of these data with the current chemical composition gives confidence that 


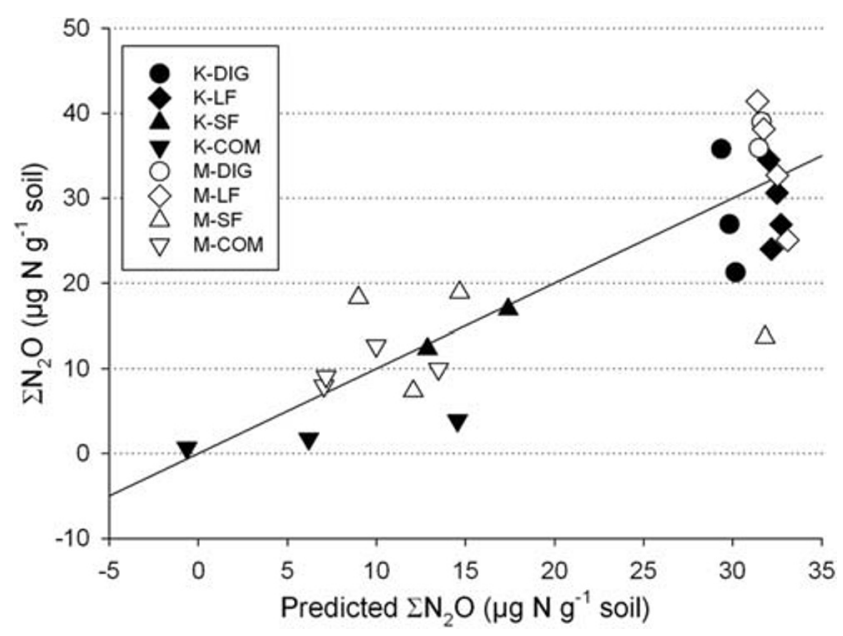

Fig. 2 Measured and predicted $\Sigma \mathrm{N}_{2} \mathrm{O}-\mathrm{N}$ efflux from soil amended with four biogas digestate qualities over a 12-day incubation at $22{ }^{\circ} \mathrm{C}$; linear prediction: $\Sigma \mathrm{N}_{2} \mathrm{O}-\mathrm{N}=28.085^{* * *}+\left(0.0476^{*} \times \Sigma \mathrm{CO}_{2}-\mathrm{C}\right)-(1.512 * * * \times$ digestate $\mathrm{C} / \mathrm{N})$, adjusted $r^{2}=0.80, * P<0.05$, *** $P<0.001$, variance inflation factor $=1.773$, Shapiro-Wilk test passed, constant variance test passed; DIG, total digestate; LF, liquid fraction; SF, separated fraction; $\mathrm{COM}$, composted solid fraction
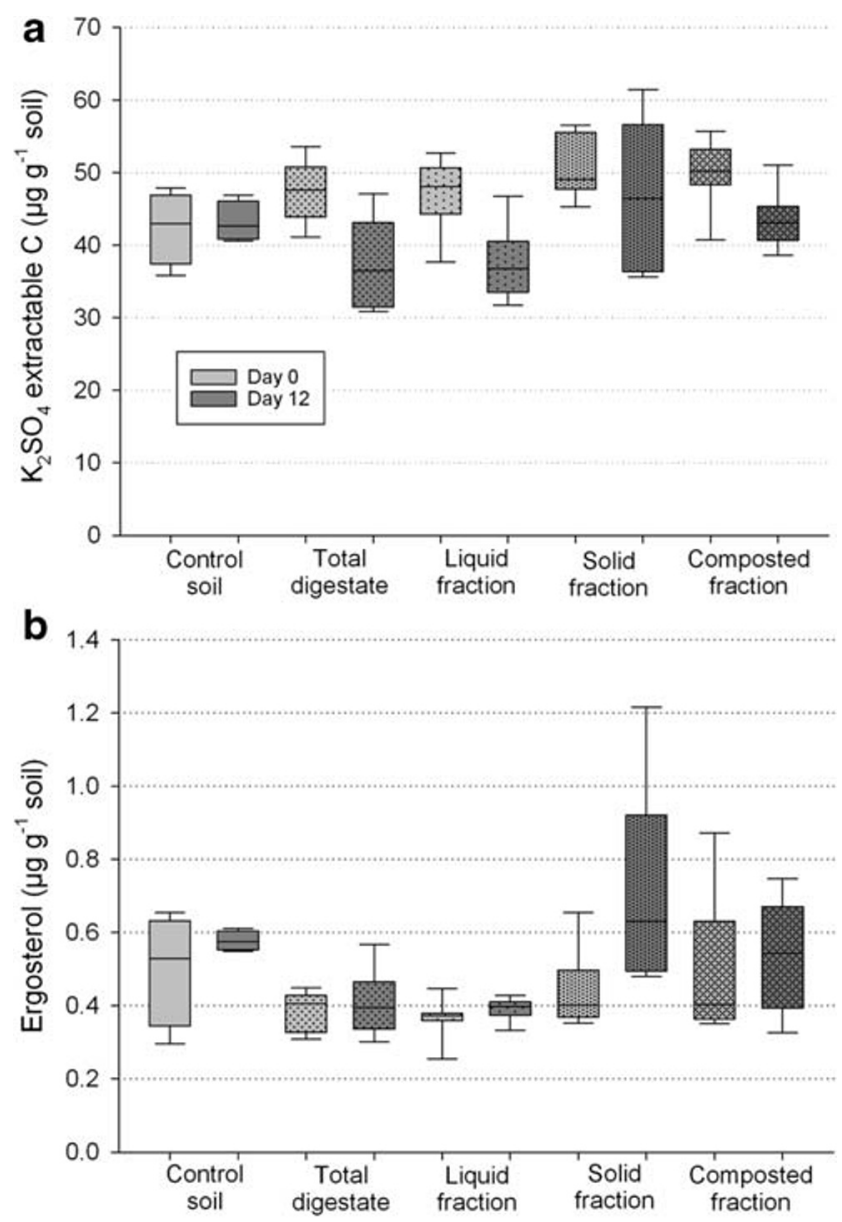

Fig. 3 Boxplots for mean contents of $\mathrm{K}_{2} \mathrm{SO}_{4}$ extractable $\mathrm{C}$ and ergosterol in soil amended with four biogas digestate qualities at the start (day 0 ) and end (day 12) of an incubation at $22^{\circ} \mathrm{C}$ sampling and chemical analytical procedures lead to reliable data on the composition of digestates.

Nearly $1 \%$ of the added digestate $\mathrm{N}$ was lost as $\mathrm{N}_{2} \mathrm{O}$ during the incubation. This loss is lower than the percentages obtained in previous studies. Sänger et al. (2010) reported an $\mathrm{N}_{2} \mathrm{O}$ loss of $1.2 \%$ from a soil amended with $100 \mathrm{~kg} \mathrm{~N} \mathrm{ha}^{-1}$ and Senbayram et al. (2009) observed an $\mathrm{N}_{2} \mathrm{O}$ loss of approximately $1.7 \%$ from a soil amended with $90 \mathrm{~kg} \mathrm{~N} \mathrm{ha}^{-1}$ applied as biogas digestate. Such low loss rates are in the range observed after inorganic fertilizer application (de Klein et al. 2001). This indicates that $\mathrm{N}_{2} \mathrm{O}$ is mainly produced during aerobic ammonium oxidation (Zhou et al. 2020), i.e. nitrifier denitrification (Kool et al. 2011; Wrage-Mönnig et al. 2018). Consequently, no additional threat of $\mathrm{N}_{2} \mathrm{O}$ production by denitrifier denitrification emerges from the application of the four digestate qualities to soil (Möller and Stinner 2009; Nicholson et al. 2017).

The fungal biomarker ergosterol was highly interrelated with $\Sigma \mathrm{CO}_{2}$-C efflux and XF fraction. Fungi are the principal decomposers of cell wall components (Schneider et al. 2012), especially lignin and lignin-cellulose complexes (Baldrian et al. 2011). In contrast, $\Sigma \mathrm{N}_{2} \mathrm{O}$ efflux and net$\mathrm{N}$ mineralisation were closely related to the $\mathrm{C} / \mathrm{N}$ ratio of the four digestate fractions. Also, the $\mathrm{N}$ turnover model CANDY emphasised the $\mathrm{C} / \mathrm{N}$ ratio as the most important parameter for predicting net- $\mathrm{N}$ mineralisation of digestates (Prays et al. 2018). However, the importance of this index should not be overestimated, as low $\mathrm{C} / \mathrm{N}$ ratios of digestates are caused by high concentrations of easily available $\mathrm{NH}_{4}{ }^{+}$and low concentrations of organic $\mathrm{C}$ components. In highly processed materials such as faeces (Jost et al. 2013) or sugar cane filter cake (Rasul et al. 2009), low $\mathrm{C} / \mathrm{N}$ ratios indicate an increased complexity of organic matter (Maynaud et al. 2017), i.e. biodegradability, and, thus, net- $\mathrm{N}$ mineralisation is reduced.

The application of the liquid fraction reduced the $\mathrm{\Sigma CO}_{2}$ efflux, presumably due to its high $\mathrm{NH}_{4}{ }^{+}$concentration. Another reason might be negative interactions of the biogas-derived microbial community and autochthonous soil microorganisms. The liquid fraction of farm $\mathrm{K}$ contained $0.25 \mathrm{mg}$ fungal GlcN g ${ }^{-1} \mathrm{DM}$ and $0.20 \mathrm{mg}$ MurN g ${ }^{-1}$ DM (Wentzel and Joergensen 2016a). Multiplying these two values by 9 and 45 (Joergensen 2018), respectively, results in 2.3-mg fungal biomass $C$ and $9.0-\mathrm{mg}$ bacterial biomass $\mathrm{C} \mathrm{g}^{-1} \mathrm{DM}$, i.e. a fungal/ bacterial ratio of 0.25 . This bacterial dominance might be a reason for the absence of any positive effects on microbial activity and biomass indices after applying the liquid fraction. The current observations are in line with the distinct physiological profiles of microbial communities, determined by the multi-substrate-induced respiration 
approach, after supplying the solid or the liquid fraction to soil (Hupfauf et al. 2016).

The $\mathrm{K}_{2} \mathrm{SO}_{4}$ extractable fraction has sometimes been considered an indicator for easily available SOC (Badalucco et al. 2010). This view has been repeatedly challenged (Wolters and Joergensen 1991; Poeplau et al. 2018), because $\mathrm{K}_{2} \mathrm{SO}_{4}$ extractable $\mathrm{C}$ contents remained constant throughout incubations, as in the current non-amended control. However, in all treatments with digestate addition, the extractable $\mathrm{K}_{2} \mathrm{SO}_{4}$ contents declined in soil, indicating that this fraction initially contained some organic components that are mineralised during incubation.

In contrast to total digestate application (Wentzel et al. 2015), the composted solid fraction has the potential to increase SOC stocks (Brito et al. 2008; Möller 2015). However, composting of the solid fraction with a $\mathrm{pH}$ of 9.3 has to deal with the serious threat of $\mathrm{NH}_{3}$ volatilization during storage (Brito et al. 2008). This risk might be reduced by adding clay to adsorb the $\mathrm{NH}_{3}$ (Chen et al. 2018). Another possibility is to add elemental sulphur (Roig et al. 2004; Gioelli et al. 2016) or sulphuric acid (Pantelopoulos et al. 2017) to decrease slurry $\mathrm{pH}$.

The decreasing DM concentration at farm $\mathrm{K}$ indicates the accumulation of water in the absence of rain-shelter roofs, which might increase the structural problems of the solid fraction. These problems could be reduced by co-composting with fibrous organic bulking material (Bustamante et al. 2012; Zeng et al. 2016), which cannot be added to biogas fermenters. A sufficient $\mathrm{O}_{2}$ supply to the solid fraction in compost piles lowers $\mathrm{N}_{2} \mathrm{O}$ and $\mathrm{NH}_{3}$ emissions (Nicholson et al. 2017). A compost site with a solid concrete floor under a roofed structure reduces excessive rewetting of the compost by rain as well as nitrate and potassium leaching into the environment (Larney and Hao 2007; Luck et al. 2008).

\section{Conclusion}

Application of the total biogas digestate or the liquid fraction to soil caused only a small $\mathrm{N}_{2} \mathrm{O}$ efflux, which was mainly derived from nitrifier denitrification. These two digestate qualities exhibited considerable net-N mineralisation rates, which could be predicted by their low $\mathrm{C} / \mathrm{N}$ ratios. Saprotrophic soil fungi were promoted after applying the solid and the composted solid fractions, both containing high concentrations of raw fibre. However, this recalcitrant organic matter led to strong net-N immobilisation induced by fungal growth. Soil microbial activity $\left(\mathrm{CO}_{2}\right.$ efflux) and biomass indices (MBC and fungal ergosterol) did not respond to the application of the liquid fraction, due to its low organic matter and high $\mathrm{NH}_{4}{ }^{+}$concentrations. Additional negative effects of the biogas-derived microbial community in the liquid fraction on autochthonous soil microorganisms could not be excluded and warrant further investigations.

Acknowledgements We would like to thank the farmers Martin Frank and Freund for their good cooperation. We highly appreciate Gabriele Dormann and Nicole Gaus for their skilled technical assistance. Laura Barduca was financed by the ERASMUS mobility program.

Funding Open Access funding enabled and organized by Projekt DEAL.

Open Access This article is licensed under a Creative Commons Attribution 4.0 International License, which permits use, sharing, adaptation, distribution and reproduction in any medium or format, as long as you give appropriate credit to the original author(s) and the source, provide a link to the Creative Commons licence, and indicate if changes were made. The images or other third party material in this article are included in the article's Creative Commons licence, unless indicated otherwise in a credit line to the material. If material is not included in the article's Creative Commons licence and your intended use is not permitted by statutory regulation or exceeds the permitted use, you will need to obtain permission directly from the copyright holder. To view a copy of this licence, visit http://creativecommons.org/licenses/by/4.0/.

\section{References}

Abubaker J, Cederlund H, Arthurson V, Pell M (2013) Bacterial community structure and microbial activity in different soils amended with biogas residues and cattle slurry. Appl Soil Ecol 72:171-180

Althaus B, Papke G, Sundrum A (2013) Technical note: use of near infrared reflectance spectroscopy to assess nitrogen and carbon fractions in dairy cow feces. Anim Feed Sci Technol 185:53-59

Bachmann S, Wentzel S, Eichler-Löbermann B (2011) Codigested dairy slurry as a phosphorus and nitrogen source for Zea mays $L$. and Amaranthus cruentus L. J Plant Nutr Soil Sci 174:908-915

Badalucco L, Rao M, Colombo C, Palumbo G, Laudicina VA, Gianfreda L (2010) Reversing agriculture from intensive to sustainable improves soil quality in a semiarid South Italian soil. Biol Fertil Soils 46:481-489

Baldrian P, Voříšková J, Dobiášová P, Merhautová V, Lisá L, Valášková V (2011) Production of extracellular enzymes and degradation of biopolymers by saprotrophic microfungi from the upper layers of forest soil. Plant Soil 338:1-15

Bauer A, Mayr H, Hopfner-Sixt K, Amon T (2009) Detailed monitoring of two biogas plants and mechanical solid-liquid separation of fermentation residues. J Biotechnol 142:56-63

Blumenstein B, Siegmeier T, Bruckhaus C, Anspach V, Möller D (2015) Integrated bioenergy and food production - A German survey on structure and developments of anaerobic digestion in organic farming systems. Sustainability 7:10709-10732

Brito LM, Coutinho J, Smith SR (2008) Methods to improve the composting process of the solid fraction of dairy cattle slurry. Bioresour Technol 99:8955-8960

Bustamante MA, Alburquerque JA, Restrepo AP, de la Fuente C, Paredes C, Moral R, Bernal MP (2012) Co-composting of the solid fraction of anaerobic digestates: obtaining of added-value materials in agriculture. Biomass Bioenergy 43:26-35

Chander K, Mohanty AK, Joergensen RG (2002) Decomposition of biodegradable packing materials jute, Biopol, BAK and their composites in soil. Biol Fertil Soils 36:344-349

Chen R, Blagodatskaya E, Senbayram M, Blagodatsky S, Myachina O, Dittert K, Kuzyakov Y (2012) Decomposition of biogas residues in 
soil and their effects on microbial growth kinetics and enzyme activities. Biomass Bioenergy 45:221-229

Chen H, Awasthi MK, Liu T, Zhao J, Ren X, Wang M, Duan Y, Awasthi SK, Zhang Z (2018) Influence of clay as additive on greenhouse gases emission and maturity evaluation during chicken manure composting. Bioresour Technol 266:82-88

Chiyoka WL, Zvomuya F, Hao X (2014) A bioassay of nitrogen availability in soils amended with solid digestate from anaerobically digested beef cattle feedlot manure. Soil Sci Soc Am J 78:12911300

Djajakirana G, Joergensen RG, Meyer B (1996) Ergosterol and microbial biomass relationship in soil. Biol Fertil Soils 22:299-304

de la Fuente C, Alburquerque JA, Clemente R, Bernal MP (2013) Soil C and mineralisation and agricultural value of the products of an anaerobic digestion system. Biol Fertil Soils 49:313-322

Gioelli F, Dinuccio E, Cuk D, Rollè L, Balsari P (2016) Acidification with sulfur of the separated solid fraction of raw and co-digested pig slurry: effect on greenhouse gas and ammonia emissions during storage. Anim Prod Sci 56:343-349

Goberna M, Podmirseg SM, Waldhuber S, Knapp BA, Garcia C, Insam $\mathrm{H}$ (2011) Pathogenic bacteria and mineral N in soils following the land spreading of biogas digestates and fresh manure. Appl Soil Ecol 49:18-25

Hupfauf S, Bachmann S, Fernández-Delgado Juárez M, Insam H, Eichler-Löbermann B (2016) Biogas digestates affect crop P uptake and soil microbial community composition. Sci Total Environ 542: $1144-1154$

Insam H, Gómez-Brandón M, Ascher J (2015) Manure-based biogas fermentation residues - Friend or foe of soil fertility? Soil Biol Biochem 84:1-14

IUSS Working Group WRB (2015) World reference base for soil resources 2014 (update 2015), international soil classification system for naming soils and creating legends for soil maps. World Soil Resources Reports

Joergensen RG (2018) Amino sugars as specific indices for fungal and bacterial residues in soil. Biol Fertil Soils 54:559-568

Joergensen RG, Wichern F (2008) Quantitative assessment of the fungal contribution to microbial tissue in soil. Soil Biol Biochem 40:29772991

Jørgensen K, Jensen LS (2009) Chemical and biochemical variation in animal manure solids separated using different commercial separation technologies. Bioresour Technol 100:3088-3096

Jost DI, Joergensen RG, Sundrum A (2013) Effect of cattle faeces with different microbial biomass content on soil properties, gaseous emissions and plant growth. Biol Fertil Soils 49:61-70

de Klein CAM, Sherlock RR, Cameron KC, van der Weerden TJ (2001) Nitrous oxide emissions from agricultural soils in New Zealand - a review of current knowledge and directions for future research. J Roy Soc New Zeal 31:543-574

Koepf HH, Schaumann W, Haccius M (1990) Bio-dynamic agriculture: an introduction. Anthroposophic Press, Hudson, New York

Kool DM, Dolfing J, Wrage N, van Groenigen JW (2011) Nitrifier denitrification as a distinct and significant source of nitrous oxide from soil. Soil Biol Biochem 43:174-178

Larney FJ, Hao X (2007) A review of composting as a management alternative for beef cattle feedlot manure in southern Alberta, Canada. Bioresour Technol 98:3221-3227

Luck JD, Workman SR, Coyne MS, Higgins SF (2008) Solid material retention and nutrient reduction properties of pervious concrete mixtures. Biosyst Eng 100:401-408

Maynaud G, Druilhe C, Daumoin M, Jimenez J, Patureau D, Torrijos M, Pourcher AM, Wéry N (2017) Characterisation of the biodegradability of post-treated digestates via the chemical accessibility and complexity of organic matter. Bioresour Technol 231:65-74
Möller K (2015) Effects of anaerobic digestion on soil carbon and nitrogen turnover, $\mathrm{N}$ emissions, and soil biological activity. A review. Agron Sustain Dev 35:1021-1041

Möller K, Müller T (2012) Effects of anaerobic digestion on digestate nutrient availability and crop growth: a review. Eng Life Sci 12: $242-257$

Möller K, Stinner W (2009) Effects of different manuring systems with and without biogas digestion on soil mineral nitrogen content and on gaseous nitrogen losses (ammonia, nitrous oxides). Eur J Agron 30: $1-16$

Møller HB, Lund I, Sommer SG (2000) Solid-liquid separation of livestock slurry: Efficiency and cost. Bioresour Technol 74:223-229

Nicholson F, Bhogal A, Cardenas L, Chadwick D, Misselbrook T, Rollett A, Taylor M, Thorman R, Williams J (2017) Nitrogen losses to the environment following food-based digestate and compost applications to agricultural land. Environ Pollut 228:504-516

Odlare M, Pell M, Svensson K (2008) Changes in soil chemical and microbiological properties during 4 years of application of various organic residues. Waste Manag 28:1246-1253

Pantelopoulos A, Magid J, Jensen LS, Fangueiro D (2017) Nutrient uptake efficiency in ryegrass fertilized with dried digestate solids as affected by acidification and drying temperature. Plant Soil 421: $401-416$

Poeplau C, Don A, Six J, Kaiser M, Benbie D, Chenu C, Cotrufo MF, Derrien D, Gioacchini P, Grand S, Gregorich E, Griepentrog M, Gunina A, Haddix M, Kuzyakov Y, Kühnel A, Macdonald LM, Soong J, Trigalet S, Vermeire ML, Rovira P, van Wesemael B, Wiesmeier M, Yeasmin S, Yevdokimov I, Nieder R (2018) Isolating organic carbon fractions with varying turnover rates in temperate agricultural soils - a comprehensive method comparison. Soil Biol Biochem 125:10-26

Prays N, Dominik P, Sänger A, Franko U (2018) Biogas residue parameterization for soil organic matter modeling. PLoS One 13: e0204121

Rasul G, Khan AA, Khan KS, Joergensen RG (2009) Immobilization and mineralization of nitrogen in a saline and alkaline soil during microbial use of sugarcane filter cake amended with glucose. Biol Fertil Soils 45:289-296

Roig A, Cayuela ML, Sánchez-Monedero MA (2004) The use of elemental sulphur as organic alternative to control $\mathrm{pH}$ during composting of olive mill wastes. Chemosphere 57:1099-1105

Sänger A, Geisseler D, Ludwig B (2010) Effects of rainfall pattern on carbon and nitrogen dynamics in soil amended with biogas slurry and composted cattle manure. J Plant Nutr Soil Sci 173:692-698

Sänger A, Geisseler D, Ludwig B (2011) Effects of moisture and temperature on greenhouse gas emissions and $\mathrm{C}$ and $\mathrm{N}$ leaching losses in soil treated with biogas slurry. Biol Fertil Soils 47:9-259

Schneider T, Keiblinger KM, Schmid E, Sterflinger-Gleixner K, Ellersdorfer G, Roschitzki B, Richter A, Eberl L, ZechmeisterBoltenstern S, Riedel K (2012) Who is who in litter decomposition? Metaproteomics reveals major microbial players and their biogeochemical functions. ISME J 6:1749-1762

Senbayram M, Chen RR, Muhling KH, Dittert K (2009) Contribution of nitrification and denitrification to nitrous oxide emissions from soils after application of biogas waste and other fertilizers. Rapid Commun Mass Spectrom 23:2489-2498

Stinner W, Möller K, Leithold G (2008) Effects of biogas digestion of clover/grass-leys, cover crops and crop residues on nitrogen cycle and crop yield in organic stockless farming systems. Eur J Agron 29: $125-134$

Tambone F, Scaglia B, D’Imporzano G, Schievano A, Orzi V, Salati S, Adani F (2010) Assessing amendment and fertilizing properties of digestates from anaerobic digestion through a comparative study with digested sludge and compost. Chemosphere 81:577-583

Tambone F, Orzi V, D'Imporzano G, Adani F (2017) Solid and liquid fractionation of digestate: mass balance, chemical characterization, 
and agronomic and environmental value. Bioresour Technol 243: $1251-1256$

Thomas BW, Li X, Nelson V, Hao X (2017) Anaerobically digested cattle manure supplied More nitrogen with less phosphorus accumulation than undigested manure. Agron J 109:836-844

Vance ED, Brookes PC, Jenkinson DS (1987) An extraction method for measuring soil microbial biomass C. Soil Biol Biochem 19:703-707

Verdi L, Kuikman PJ, Orlandini S, Mancini M, Napoli M, Dalla Marta A (2019) Does the use of digestate to replace mineral fertilizers have less emissions of $\mathrm{N}_{2} \mathrm{O}$ and $\mathrm{NH}_{3}$ ? Agric Forest Meteorol 269-270: $112-118$

Wentzel S, Joergensen RG (2016a) Quantitative microbial indices in biogas and raw cattle slurries. Eng Life Sci 16:231-237

Wentzel S, Joergensen RG (2016b) Effects of biogas and raw slurries on grass growth and soil microbial indices. J Plant Nutr Soil Sci 179: 215-222

Wentzel S, Schmidt R, Piepho HP, Semmler-Busch U, Joergensen RG (2015) Response of soil fertility indices to long-term application of biogas and raw slurry under organic farming. Appl Soil Ecol 96:99107
Wolters V, Joergensen RG (1991) Microbial carbon turnover in beech forest soils at different stages of acidification. Soil Biol Biochem 23: 897-902

Wrage-Mönnig N, Horn MA, Well R, Müller C, Velthof G, Oenema O (2018) The role of nitrifier denitrification in the production of nitrous oxide revisited. Soil Biol Biochem 123:A3-A16

Wu J, Joergensen RG, Pommerening B, Chaussod R, Brookes PC (1990) Measurement of soil microbial biomass $\mathrm{C}$ by fumigation-extraction - an automated procedure. Soil Biol Biochem 22:1167-1169

Zeng Y, de Guardia A, Dabert P (2016) Improving composting as a posttreatment of anaerobic digestate. Bioresour Technol 201:293-303

Zhou W, Jones DL, Hu R, Clark IM, Chadwick DR (2020) Crop residue carbon-to-nitrogen ratio regulates denitrifier $\mathrm{N}_{2} \mathrm{O}$ production post flooding. Biol Fertil Soils 56:825-838

Publisher's note Springer Nature remains neutral with regard to jurisdictional claims in published maps and institutional affiliations. 